Ann. Biol. anim. Bioch. Biophys., 1975, 15 (2), 215-220.

\title{
THE TIME OF OVULATION IN HEIFERS AFTER PROGESTIN (SC $9880 ;$ SC 21009) TREATMENT
}

\author{
D. F. WISHART \\ Scarle Research Laboratories, \\ High Wycombe (England)
}

\section{SUMMARY}

Synchronisation of oestrus in cattle using progesterone or synthetic progestins for periods of I8-2I days is associated with a subfertility at the induced oestrus, normal levels of fertility returning at the subsequent oestrus. Since oestrus is the behavioural sign by which cattle are identified as being ready for insemination, an abnormal time relationship between oestrus and ovulation can be expected to lead to reduced levels of fertility. The duration of oestrus and the time of ovulation after treatment with two progestins - SC 9880 and SC 21009 - have been studied in heifers by repeated observation of oestrus behaviour at short intervals and by endoscopy, with a view firstly to identify any abnormalities and secondly with a view to determining the possibilitity of inseminating at a predetermined time after treatment rather than in relation to oestrus in each animal. The results indicate that in spite of significant differences in fertility between the progestins, no temporal abnormalities exist, and that with SC 21009 treatment for 9 days insemination at a predetermined time becomes a distinct possibility.

\section{INTRODUC'TION}

It is now generally accepted that progestin treatment for I8-2I days is associated with reduced fertility in synchronised cattle, normal fertility returning at the subsequent cycle. Oestrus is the behavioural sign by which cattle are identified as being ready for insemination. Optimum fertility follows insemination between midoestrus to six hours after the end of the oestrus (LAING, I970). The importance of timing insemination correctly reflects the disparity between the survival time of the male and female gametes in the genital tract. The average survival time of sperm has been estimated at about 30 hours (LAING, I945) whilst that of the ovum is probably only a few hours. An abnormal timing of ovulation relative to oestrus can be expected to result in a reduction of fertility when the time of insemination is related to oestrous detection. There is evidence that progestin treatment may affect the duration of oestrus and the time of ovulation in heifers. (Wictravk et al., r967) reported a significant shortening of oestrus and a significant legthening of 
the interval from oestrus to ovulation in heifers fed $500 \mathrm{mg}$ dihydroxyprogesterone acetophenide for 20 days. In this laboratory two progestins with high activity for suppressing oestrus and ovulation in heifers (WISHART, I972) have been used to synchronise oestrus. Following treatment the duration of oestrus has been measured by observation and the time of ovulation has been determined by laparoscopy using the method described by WISHART and SNOWBALL (I973).

\section{MATERIALS AND METHODS}

A total of zro cyclic heifers (Friesian and Friesian $\times$ Hereford) were used in two experiments. The animals, aged I5-1 8 months, weighed between $295^{-340} \mathrm{~kg}$, and were fed $2.0 \mathrm{~kg}$ rolled barley, $2.0 \mathrm{~kg}$ concentrates daily with barley straw and water ad lib. They also had free access to a mineral mixture.

$\mathrm{SC} 9880$ was dissolved in sesame oil $(0.4 \mathrm{mg} / \mathrm{ml})$ with to $\mathrm{p}$. roo benzyl alcohol added as a bacteriostat. $2.4 \mathrm{mg}$ SC 9880 were injected daily intramuscularly. SC 21009 was administered in one of two ways, by daily intramuscular injection of $0.2 \mathrm{mg}$ dissolved in sesame oil (0. $1 \mathrm{mg} / \mathrm{ml})$ with ro p. roo benzyl alcohol or by subcutaneous polymer implants containing 6 . o mg SC 21009 . At the time of implantation $2.0 \mathrm{ml}$ sesame oil containing $5.0 \mathrm{mg}$ oestradiol valerate and 3.0 $\mathrm{mg}$ $\mathrm{SC} 2$ Ioog were injected intramuscularly. The implants, measuring $18 \mathrm{~mm} \times 3 \mathrm{~mm}$ and weighing $0.125 \mathrm{~g}$, were placed subcutaneously in the ear using a simple narrow bore trocar and cannula. Treatment by daily injection continued for 2 I days. Implants were removed after 9 days in situ.

In Experiment I, I 20 heifers in oestrus after treatment with daily progestin injections were observed every two hours from 08.00-24.00 hours and again at 04.00 hours. Beginning 6 hours after the end of oestrus heifers were examined by endoscopy. Animals were allocated on a random basis to subgroups corresponding to the time of endoscopy $(6,9,12,15,18$ or 24 hours after the end of oestrus). Ten animals from each treatment were examined at each time interval. During the observation period 60 similar animals exhibiting oestrus spontaneously and receiving no treatment were similarly examined. They acted as controls. In those animals which had not ovulated by the time of endoscopic examination the definitive follicle was, where possible, identified by its size. An attempt to measure the diameter of the follicle was made using graduations marked on the Jacobs-Palmer grasping forceps used to hold the mesovarian ligament and rotate the ovary. Definitive follicles were classified as medium-sized (5-10 $\mathrm{mm}$ in diameter) or large ( $>$ 10 $\mathrm{mm}$ in diameter).

In Experiment II, 30 heifers were treated with SC 2 roog implants. After implant removal, observations for oestrus were made at four hourly intervals for 4 days. Starting 8 hours after the end of oestrus each heifer was examined by endoscopy every 4 hours until ovulation occurred.

\section{RESULTS}

In experiment I the mean duration of oestrus in the SC $9880, \mathrm{SC} 2 \mathrm{I} 00 \mathrm{~g}$ and control groups were $\mathrm{I}_{2} .67$ (S. D. 4.48) hours, I5.47 (S. D. 6.I9) hours and I4.00 (S.D. 4.69) hours respectively. $\mathrm{SC} 9880$ treatment significantly $(\mathrm{P}=0.05)$ reduced the duration of oestrus. The difference in duration of oestrus in SC 21009 and control groups did not attain statistical significance. Table I shows that treatment neither affected the timing nor pattern of ovulation; also it was unusual for ovulation to occur earlier than 9 hours after oestrus. Table 2 illustrates that for the majority of animals examined at 6 or 9 hours it was impossible to detect a follicle which could be classified by its size as definitive. At the 6 hours stage $93.3 \mathrm{p}$. Ioo of 30 animals examined, and at the 9 hours stage 58.6 p. Ioo of 29 animals which had not ovulated, 
did not have a follicle larger than $3-5 \mathrm{~mm}$ in diameter in either ovary. By $\mathrm{I} 2$ hours after oestrus, the pattern had changed with $94 \mathrm{p}$. Ioo of $\mathrm{I} 8$ heifers examined then or later possessing a medium or large-sized definitive follicle in one or other ovary.

TABLE I

Number of heifers ovulated of thase examined $(n=10)$ by intervals (hours) after oestrus

\begin{tabular}{|c|c|c|c|c|c|c|c|c|c|}
\hline \multirow{2}{*}{ Treatment } & \multirow{2}{*}{$\begin{array}{l}\text { Total } \\
\text { treated }\end{array}$} & \multirow{2}{*}{$\begin{array}{c}\text { Total } \\
\text { examined }\end{array}$} & \multicolumn{6}{|c|}{ Number ovulated at intervals after oestrus } & \multirow{2}{*}{$\begin{array}{c}\text { Total } \\
\text { ovulated }\end{array}$} \\
\hline & & & $6 \mathrm{hr}$ & $9 \mathrm{hr}$ & $12 \mathrm{hr}$ & $15 \mathrm{hr}$ & $18 \mathrm{hr}$ & $24 \mathrm{hr}$ & \\
\hline \multicolumn{10}{|c|}{ 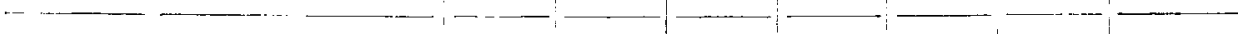 } \\
\hline SC 9880 & 67 & 60 & $\mathrm{Nil}$ & 1 & 4 & 4 & 9 & 10 & 28 \\
\hline SC 21009 & 66 & 60 & Nil & $\mathrm{Nil}$ & 4 & 6 & 9 & 10 & 29 \\
\hline \multirow[t]{2}{*}{ Control } & - & 60 & Nil & Nil & 4 & 6 & 9 & 10 & 29 \\
\hline & Total & 180 & Nil & 1 & 12 & 16 & 27 & 30 & 86 \\
\hline
\end{tabular}

TABLE 2

Follicular development in heifers which had not ovulated by the time of endoscopy

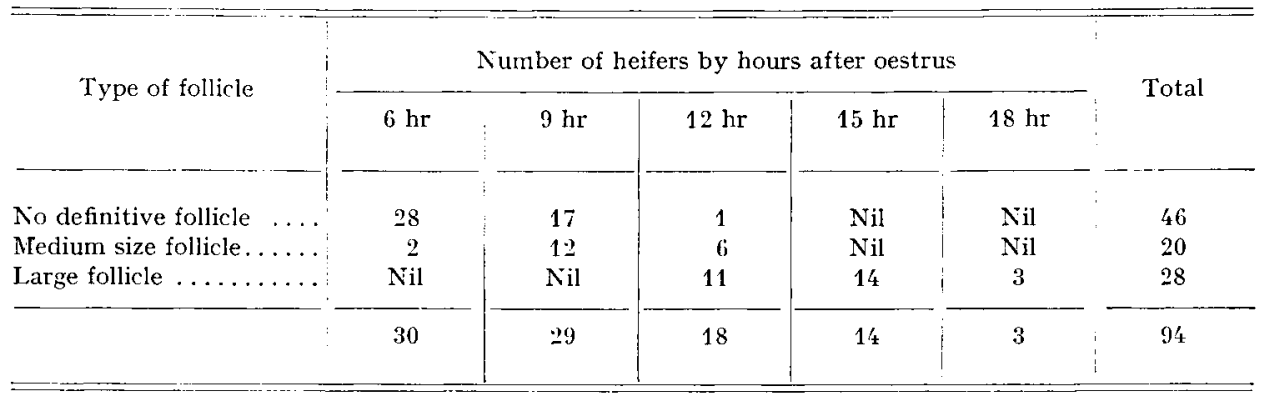

In Experiment II, twenty-six (86.7 p. Ioo) heifers were in oestrus. The mean duration of oestrus was I7.8 hours (S.D. $=6.4$ ). None of the heifers ovulated earlier than Io hours after the end of treatment (table 3 ). The accumulated percentage of heifers ovulating of these in oestrus was $0,23,69.2,96 . \mathrm{I}$ and $\mathrm{I}$ oo at $48,60,72,84$ and 96 hours respectively after implant removal. Of the 4 heifers not observed in oestrus within four days of the end of treatment, 3 were found to have ovulated recently when examined by endoscopy on Day 5 . These results indicate that $\mathrm{SC} 2$ Ioog implant treatment synchronises ovulation to an extent which should permit insemination of animals at one or more predetermined times following implant removal with the expectation of similar levels of fertility to those animals inseminated on detection of oestrus after implant treatment. 
TABLE 3

Time relationships of oestrus and ovulation in heifers treated with SC 21009 implants

\begin{tabular}{|c|c|c|c|c|c|}
\hline Parameters & Mean & S. D. & S. E. & Min. & Max. \\
\hline $\begin{array}{l}\text { Interval to oestrus ... } \\
\text { Duration of oestrus... } \\
\text { End of oestrus to ovu- } \\
\text { lation } \ldots . . . \ldots \ldots \\
\text { End of treatment to } \\
\text { ovulation ......... }\end{array}$ & $\begin{array}{l}36.0 \\
17.8 \\
14.6\end{array}$ & $\begin{array}{l}8.9 \\
6.4 \\
2.6\end{array}$ & $\begin{array}{l}1.7 \\
1.2 \\
0.5\end{array}$ & $\begin{array}{r}214 \\
4 \\
10\end{array}$ & $\begin{array}{l}52 \\
28 \\
20\end{array}$ \\
\hline
\end{tabular}

\section{DISCUSSION}

The data presented on follicle development detected by a thorough endoscopic examination conflicts with the widely held view that a definitive follicle is palpable per rectum at some stage during oestrus (NALBAndov and CASIDA, I942 ; EDWARds, I965 ; MORROW, I969; RoBERTS, I97I). Using laparotomy for close follicular examination, Dufour et al., (I972) were able to identify with a high degree of accuracy from Day 18 of the cycle onwards, the follicle which would ovulate. In the majority of cases it was the largest follicle present at the time of examination. From the observations in Experiment II it has been confirmed that the follicle which would have been classified in Experiment I as medium or large-sized is indeed that which will ovulate in due course. The apparent conflict between these data may be explained in part by the comparatively infrequent observations for oestrus made by some of the authors. For instance, Morrow (I959) observed for oestrus twice daily and EDWARDS (I965) took the oestrous phase of the cycle as I.8 days. The long interval between observations could account for the discrepancies observed. However, there may be a further explanation. Nalbandov and CASIDA (I942) conducted observations for oestrus at approximately two-hour intervals and found by rectal palpation that the follicle increases markedly in size beginning late in oestrus at which stage it protruded from the surface. DonALDSON and HANSEL (I968) noted a discrepancy between the diameter of follicles estimated by observing the surface of the ovary and the estimate made following histological sectioning. For the majority of follicles the measurements varied by as little as $2 \mathrm{~mm}$ but for some $\mathrm{I} 6 \mathrm{p}$. Ioo the maximum diameter estimated by sectioning was some $5^{-\mathrm{I}} 4 \mathrm{~mm}$ larger than the estimate based on the portion of the follicle visible from the surface of the ovary. Palpation therefore may allow earlier identification of the definitive follicle by its size since it may be possible to palpate the portion embedded in the stroma which is invisible to endoscopic examination.

Oestrous detection is a time consuming task. It is the responsability of the farmer to detect oestrus accurately and to call for artificial insemination at the appropriate time. Non-return to service rates are known to fall when a number 
of cows are inseminated at one visit. FRAPELI. (I969) attributed this to inaccurate oestrous detection. Oestrous detection becomes more difficult in a synchronised group due to the varying degrees of sexual activity being shown by the majority of animals. Relieving the farmer from the responsibility of detecting oestrus by relating the time of insemination to the end of a synchronisation treatment would clearly be advantageous. The data presented here indicates that this may be possible using the SC 2Ioog implant without the need for an additional oestrogen or Human Chorionic Gonadotrophin injection at the end of treatment. Such modifications to progestin treatments have interfered with normal expression of oestrus and have resulted in low levels of fertility (Boyd and TASker, I97I ; Roche and Crowley, I973).

\title{
Colloque: Control of sexual cycles in domestic animals October 27-30, 1974, Nouzilly.
}

\author{
RÉSUMÉ, \\ MOMENT DE L'OVULATION CHEZ LES GÉNISSES \\ APRÈS TRAITEMENT PAR UN PROGESTOGÈNE (SC 9880, SC 2IOO9)
}

La synchronisation des oestrus chez les bovins avec la progestérone ou des progestagènes de synthèse pendant $\mathbf{I} 8$ à $2 \mathrm{r}$ jours est associée avec une subfertilité à l'oestrus induit. De bons niveaux de fertilité sont retrouvés à l'œestrus suivant. Comme l'œestrus est la manifestation d'un comportement par lequel les bovins sont identifiés pour être inséminés, une relation chronologique anormale entre cestrus et ovulation pourrait exister et conduire à des niveaux réduits de fertilité. La durée de l'œstrus et le moment de l'ovulation après traitement avec 2 progestagènes $\mathrm{SC} 9880$ et $\mathrm{SC} 21009$ ont été étudiés chez des génisses après des observations répétées de comportement d'cestrus à intervalles courts et par endoscopie, ceci afin d'abord d'identifier les anomalies et ensuite de déterminer la possibilité d'insémination à un moment prédéterminé après le traitement plutôt qu'en relation avec l'œestrus de chaque animal.

Les résultats indiquent qu'en dépit de différentes significatives de fertilité entre progestagènes, aucune anomalie chronologique n'existe et qu'avec le traitement SC 2 Ioog de 9 jours, l'insémination à un moment prédéterminé est une possibilité réelle.

\section{REFERENCES}

BOYD I. J., TASkrR J. B., I97r. Fertility of oestrus synchronised dairy cattle treated with gonadotrophins and inseminated at a predetermined time. Vet. Rec., 89, 632-635.

Donaldox L. E., Hansel W., Ig68. Cystic corpora lutea and normal and cystic graafian follicles in the cow. Aust. Vet. J., 44, 304-308.

Dufour J., Whitmore H. L., Ginther O. J., Casida L. E., I972. Identification of the ovulating follicle by its size on different days of the estrous cycle in heifers. J. Anim. Sci., 34, 85-87.

EDWARDS M. J., I965. Observations on the anatomy of the reproductive organs of cows. N. $Z$. Vet. $J ., 13,25 \cdot 37$

Frapell J. P., 1969. The use of M. M. B. Production and Services data. II. The use of A. I. Centre Records in Applied Science. Tet. Rec., 84, $38 \mathrm{I}-385$.

LAING J. A., I 945. Observations on the survival time of the spermatozoa in the genital tract of the cow, and its relation to fertility. J, A gric. Sci., 35, 72-83.

LAING J. A., r97o. The ovulation-insemination time relationship and fertility. In : Fertility and Infertility in the Domestic Animals. Ed. J. A. LAING. Published Bailiere, Tindall and Cassell. Chapter Io pages 355-356.

Morrow D. A., I969. Estrous behaviour and ovarian activity in prepuberal and postpuberal dairy heifers. J. Dairy Sci., 52, 224-227. 
Nalbandoy A., Casida L. E., 1942. Ovulation and its relation to estrus in cows. J. Anim. Sit, 1, I 89 - I 98 .

Roberts S. J., 1971. Infertility in the cow. In Veterinary Obstetrics and Genital Diserases. Ch. XIlI, p. 376-39o. 2nd Ed. Ithaca, New York.

Roche J. F., Crowley J. P., I973. The fertility of heifers inseminated at predetermined intervals following treatment with $\mathrm{MGA}$ and $\mathrm{HCG}$ to control ovulation. J. Reprod. Fert, 35, 21 I-216.

Wiltbank J. N., Shlmway R. P., Parker W. R., Zimmerman D. R., 1967. Duration of estrus, time of ovulation and fertilisation rate in beef heifers synchronised with dihydroxyprogesterone acetophenide. J. Anim. Sci., 26, 764-767.

Wishart D. F., I972. Identification of steroids of high activity for control of the oestrus cycle in the dairy heifer. J. Reprod. Fert., 30, 333-334.

Wishart D. F., Sxowbali. J.-B., 1973. Endoscopy in Cattle: Observation of the ovary in situ. Tit. Rec., 92, I39-142. 